CURRENT

Jurnal Kajian Akuntansi dan Bisnis Terkini

https://current.ejournal.unri.ac.id

\title{
REAKSI PASAR MODAL ATAS KEBIJAKAN KENAIKAN CUKAI ROKOK DI INDONESIA
}

\author{
Erik Alexander Gani ${ }^{1 *}$, Yulia Efni ${ }^{2}$, Andewi Rokhmawati ${ }^{3}$ \\ ${ }^{123}$ Program Studi Akuntansi, Fakultas Ekonomi dan Bisnis, Universitas Riau, Pekanbaru \\ *E-mail: erikalexander2758@yahoo.com
}

\begin{tabular}{l} 
Keywords \\
\hline Abnormal Return, \\
Trading Volume Activity, \\
Bid-Ask Spread and Event \\
Study
\end{tabular}

\section{Article informations}

Received:

2020-08-30

Accepted:

2021-06-15

Available Online:

2021-07-27

\begin{abstract}
This study aims to analyze the reaction of the capital market to the increase in cigarette excise in Indonesia. This study focuses on cigarette companies listed on the Indonesia Stock Exchange as an increase in excise tax has an impact on the cigarette industry. There are 4 companies that are included in the cigarette industry which are the samples of this study. This study uses an event study to examine the effect of Abnormal Return, Trading Volume Activity and Bid-Ask Spread before and after the increase in excise tax. The findings of this study are that there is a difference in abnormal returns both before and after the announcement of the policy on the increase in cigarette excise in 2020. Other findings indicate that there is no difference in trading volume activity both before and after the announcement of the policy for the increase in cigarette excise in 2020. Other findings indicate that there is no difference in bids. ask spread both before and after the announcement of the 2020 cigarette excise tax increase.
\end{abstract}

\section{PENDAHULUAN}

Industri rokok sangat berperan penting dalam rangka menggerakkan ekonomi di Indonesia, karena industri rokok juga bergantung pada industri-industri lainnya yang saling terkait yang membentuk efek domino pada keseluruhan industri terkait yang berhubungan dengan industri rokok. Menurut Kementerian Perindustrian Republik Indonesia (2020) industri rokok dan industri terkait menyerap sekitar 6.1 juta orang terutama wilayah penghasil tembakau, cengkeh dan pusat-pusat produsen rokok. Dengan pertimbangan industri rokok yang masih menjadi harapan masyarakat Indonesia dalam mencari penghasilan, industri rokok dikembangkan tanpa mengabaikan efek kesehatan konsumsi rokok itu sendiri.

Kebijakan mengenai kenaikan cukai rokok di Indonesia pada tahun 2020 mempengaruhi harga saham perusahaan rokok. Harga saham yang turun akan mengakibatkan actual return dan expected return menjadi turun yang disebabkan reaksi pada abnormal return baik positif maupun negatif. Harga Saham yang turun juga akan mengakibatkan selisih 
anatar harga jual dan beli semakin kecil sehingga bid-ask spread akan menurun yang disebabkan meningkatnya transaksi jual dan beli dari saham perusahan rokok sehingga trading volume activity akan meningkat.

Ada fenomena yang menunjukkan bahwa jumlah industri skala kecil dan menegah yang menghasilkan rokok semakin turun dari tahun ke tahun sedangkan industri rokok yang memiliki skala yang lebih besar semakin berkembang untuk melakukan pengembangan bisnisnya. Investasi asing yang masuk ke Indonesia untuk menjalankan bisnis industri rokok didasari masih besarnya konsumsi rokok di Indonesia. Berdasarkan laporan The Tobacco Atlas (2020) yang sangat menarik untuk diteliti terutama konsumsi rokok di dunia masih sangat tinggi ini didasari dengan jumlah rokok yang dikonsumsi dala sethaun yaitu mencapai 5,7 triliun batang rokok. Walaupun jumlah penikmat rokok di negara maju mengalami penurunan, tetapi tidak dengan jumlah penikmat rokok di negara berkembang yang mana semakin meningkat.

Berdasarkan laporan (The Tobacco Atlas, 2020) Pengguna rokok di negara berkembang semakin meningkat. Menurut laporan (The Tobacco Atlas, 2020) pengguna rokok di Indonesia diproyeksikan antara tahun 2015 sampai dengan tahun 2025 bertambah sekitar 24 juta orang sedangkan jumlah rokok yang dikonsumsi di Indonesia juga diketahui cukup tinggi yaitu mencapai 1.675 batang per kapita dalam satu tahun. Padahal efek kesehatan dari konsumsi rokok diketahui sangat berbahaya. Menurut (The Tobacco Atlas, 2020) selain nikotin, didalam rokok juga memiliki terdapat berbagai jenis bahan kimia yaitu sekitar lebih dari 7.000 bahan kimia berbahaya termasuk arsenik, sianida, maupun zat berbahaya lainnya, dan lebih dari 50 zat yang berbahaya bagi tubuh manusia yang terkandung dalam rokok yang merupakan karsinogenik atau zat yang dapat memicu munculnya sel kanker.

Kebijakan kenaikan cukai yang dilakukan oleh pemerintah bukan hanya mempengaruhi kebijakan perusahaan juga dapat mempengaruhi pasar modal. Menurut Jogiyanto (2003) pasar modal akan beroperasi secara optimal apabila memiliki dua syarat penting yaitu pasar yang efisien dan adanya perlindungan yang memadai bagi investor sehingga perusahaan dapat menggunakan pasar modal sebagai sumber pembiayaan yang mudah bagi perusahaan. Menurut Fama (1970) Pasar modal dibilang efisien jika harga saham dari sebuah perusahaan mencerminkan nilai fundamental dari perusahaan tersebut serta bagaimana investor menilai prospek adanya laba dari perusahaan tersebur di masa yang akan datang.

Menurut Kasmir (2012) sebagai sebuah instrumen dalam kegiatan perekonomian, 
pasar modal akan dipengaruhi oleh lingkungan baik ekonomi maupun politik, pengaruh lingkungan mikro seperti kinerja pada perusahaan, berubahnya strategi perusahaan, pengumuman penyebaran dividen oleh perusahaan, dan pengumuman laporan keuangan di perusahaan yang akan membuat pelaku pasar modal bereaksi. Selain itu, lingkungan ekonomi makro yang berubah akan mengakibatkan terjadinya hal seperti perubahan pada suku bunga bank, kurs, inflasi, regulasi dan deregulasi yang dilakukan oleh pemerintah akan ikut mempengaruhi pergerakan harga saham dan volume perdagangan di pasar modal.

Pada pasar modal yang efisien, harga saham mencerminkan secara menyeluruh informasi yang terdapat di pasar. Pada pengujian efisiensi pasar, informasi dapat menjadi penentu bagi perubahan harga saham tersebut dari waktu ke waktu dan dari penerima informasi. Menurut Fama (1970) pada informasi yang dapat diakses tersebut dapat ditentukan hipotetikal untuk menentukan efisiensi pasar modal, yaitu bentuk lemah (weak form efficient), bentuk setengah kuat (semistrong form efficient), dan bentuk kuat (strong form efficient).

Menurut Fama (1970) efek dari tingkat efisiensi pasar adalah munculnya Hipotesis Efisiensi Pasar atau Efficient Market Hypothesis (EMH). Efficient Market Hypothesis $(\mathrm{EMH})$ terdiri dari dua jenis pendekatan yaitu analisis fundamental dan analisis teknikal, adapun kedua analisis ini berhubungan dengan penilaian atas harga dari sebuah saham. Analisis teknikal didasari bahwa harga saham ditentukan dari penawaran dan permintaan yang ada di pasar terhadap suatu saham.

Pada pasar modal yang efisien analisis fundamental yang kuat di perusahaan rokok, informasi seperti kenaikan cukai rokok tidak dapat mempengaruhi harga saham karena return yang diberikan normal sedangkan Ariyanti (2016) menyampaikan pasar modal yang memiliki bentuk semi kuat yang dipengaruhi informasi yang bersifat historis dan informasi yang dipublikasi seperti halnya di Indonesia, informasi mengenai kenaikan cukai dapat menyebabkan reaksi investor yang cukup besar terutama investor jangka pendek yang memanfaatkannya untuk mendapatkan abnormal return.

Berdasarkan penelitian (Ariyanti, 2016) mengenai kebijakan pengendalian tembakau dianalisis sebagai faktor yang mempengaruhi investor yang berada di pasar modal. Hasil dari uji hipotesis baik sebelum maupun sesudah pengumuman pada kebijakan menghasilkan perbedaan ARR (Average Abnormal Return) namun tidak terlalu signifikan. Sama halnya dengan penelitian (Ammann et al, 2015) mengenai efek pengumuman dari convertible securities (obligasi CoCo) yang diterbitkan oleh bank global antara Januari 2009 sampai dengan Juni 2014. Hasil penelitian menemukan bahwa pengumuman dari obligasi CoCo 
berhubungan dengan abnormal return saham yang positif dan CDS negatif memberikan perubahan pada periode pasca pengumuman dalam waktu singkat. Sama halnya dengan penelitian (Janiantari, 2014) melakukan penelitian mengenai perbedaan bid-ask spread dan abnormal return sebagai dampak dari pengumuman stock split. Hasilnya menunjukkan bahwa terdapat perbedaan signifikan dari bid-ask spread dan abnormal return baik sebelum dan sesudah pengumuman pemecahan saham.

Sedangkan penelitian Laili (2017) melakukan penelitian untuk menganalisis abnormal return dan trading volume activity sebelum dan sesudah pengumuman kenaikan cukai rokok periode 2016 dengan hasil tidak ada perbedaan yang signifikan pada rata-rata abnormal return dan trading volume activity. Sama halnya dengan penelitian Vahini \& Putra (2015) melakukan penelitian untuk menganalisis adanya reaksi pasar modal terhadap publikasi laporan keuangan tahunan dalam kelompok saham indeks LQ45 pada tahun 2009 sampai 2013 Hasilnya Tidak adanya perbedaan reaksi investor yang menyebabkan perubahan rata-rata abnormal return serta volume perdagangan saham baik sebelum maupun sesudah publikasi laporan keuangan secara statistik. Sama halnya dengan penelitian (Gumanti, Tatang Ari et al, 2018) yang melakukan penelitian untuk menganalisa dampak kecelakaan pesawat AirAsia pada 28 desember 2014 terhadap perusahaan travel dan penginapan yang terdapat di Pasar modal Malaysia. Hasilnya Tidak terdapat signifikan abnormal return sebelum dan sesudah event. Tidak terdapat perbedaan signifikan pada trading volume activity sebelum dan sesudah event. Sama halnya dengan penelitian Prasiska (2018) melakukan penelitian mengenai analisis abnormal return dan bid-ask spread sebelum dan sesudah stock split pada perusahaan go public di BEI Tahun 2013 sampai dengan 2017 dengan hasil penelitian yang menyatakan terdapat perbedaan abnormal return baik sebelum dan sesudah pengumuman stock split dan tidak terdapat perbedaan bid-ask spread baik sebelum dan sesudah pengumuman stock split.

Dari beberapa penelitian yang meneliti dampak berlakunya regulasi terhadap adanya reaksi di pasar modal yang pernah dilakukan, pemberlakuaan regulasi ditetapkan sebagai informasi yang dapat mengakibatkan timbulnya abnormal return pada saham suatu perusahaan. Penelitian ini mengkaji respon pasar modal terhadap kebijakan kenaikan cukai rokok yang sudah dan akan diterapkan dapat berpengaruh terhadap pasar modal yang secara spesifik bersinggungan.

Pengambilan sebuah keputusan dalam berinvestasi pada kondisi yang stabil, investor hanya melihat berapa hasil atau pendapatan dari investasi pada sebuah perusahaan. Sementara dalam pengambilan sebuah keputusan dalam berinvestasi pada kondisi yang tidak stabil, 
investor perlu melihat berapa besar risiko yang timbul apabila berinvestasi dalam perusahaan tersebut. Dalam kondisi yang tidak stabil, hal yang diperlukan investor dalam mengambil keputusan dalam berinvestasi adalah meramalkan return yang diharapkan (expected return) dan memperhitungkan penyimpangan return sesungguhnya terhadap return yang diharapkan.

Penelitian ini mengkaji tentang reaksi yang ditimbulkan pasar modal dengan kesesuaiannya dengan teori pasar modal efisien yang diutarakan oleh (Fama, 1970). Selain itu, penelitian ini diharapkan dapat menjadi sumber studi literatur terutama penelitian yang berhubungan dengan event study yang mana kebijakan sebagai acuan perubahan sehingga penelitian selanjutnya dapat mengembangkan pola dari penelitianyang sudah ada sebelumnya.

Dari beberapa penelitian mengenai dampak dari berlakunya kebijakan terhadap reaksi yang ditimbulkan di pasar modal yang pernah dilakukan, pemberlakuaan kebijakan bisa dibilang sebagai landasan informasi yang dapat mengakibatkan abnormal return pada saham suatu perusahaan. Penelitian ini mengkaji respon pasar modal terhadap kebijakan kenaikan cukai rokok yang sudah dan akan diterapkan dapat berpengaruh terhadap pasar modal yang secara spesifik bersinggungan. Penelitian terdahulu yang dilakukan oleh Jennifer \& Komardi (2015), Fahmi (2016), Bei (2015), dan Puteri (2017) hanya menggunakan abnormal return dan trading volume activity sebagai variabel dan model yang digunakan adalah market adjusted model. Dalam rangka melengkapi maupun memperbaiki penelitian terdahulu, selain menguji abnormal return dan trading volume activity, penelitian ini juga menguji seberapa besar biaya transaksi memiliki dampak terhadap strategi dan keputusan trading. Jika biaya transaksi rendah maka volume perdagangan akan meningkat, begitu pula jika biaya transaksi tinggi maka strategi buy-and hold akan dilakukan oleh investor dapat mempengaruhi volume perdagangan melalui variabel bid-ask spread dan penelitian ini juga menggunakan CAPM sebagai model perhitungan expected return sehingga hasil yang dihasilkan lebih akurat daripada hanya menggunakan indeks pasar sebagai acuan.

Berdasarkan fenomena-fenomena yang ada, kebijakan merupakan suatu hal yang diduga dapat memicu reaksi di pasar modal dengan asumsi kebijakan yang menjadi variabel mengandung informasi yang berhubungan langsung dengan industri terkait yang ada di bursa efek Indonesia. Penelitian ini dilakukan pada perusahaan rokok dikarenakan yang memiliki dampak langsung dari kebijakan kenaikan cukai yaitu perusahaan rokok. Penulis menduga bahwa pasar akan bereaksi dengan adanya kebijakan kenaikan cukai rokok sehingga penelitian ini bertujuan untuk meneliti perbedaan average abnormal return, average trading volume activity dan bid-ask spread sebelum dan sesudah pengumuman kebijakan kenaikan cukai rokok tahun 2020. 


\section{PENGEMBANGAN HIPOTESIS}

Dalam pasar modal, ada sebuah hipotesis yang digunakan dalam penelitian yang berhubungan dengan event study yaitu hipotesis pasar efisien. Hipotesis pasar efisien mengungkapkan sebuah konsep keterkaitan antara harga sebuah saham dengan informasi yang menyebar di pasar modal. Di pasar modal, investor yang memiliki kemampuan untuk mengakses informasi yang lebih banyak dan jumlah yang besar akan lebih baik dalam memprediksi harga dari saham sehingga dia memiliki potensi keuntungan yang lebih besar daripada yang tidak memiliki akses atas informasi. Berdasarkan dari informasi yang diberikan oleh pasar, pasar efisien dapat dibagi menjadi 3 bentuk, yaitu pasar efisien bentuk lemah, semi kuat, dan kuat (Fama, 1970).

Industri yang mengelola tembakau memiliki peran yang cukup besar atas penerimaan negara melalui pajak seperti pajak penjualan maupun cukai, penyerapan tenaga kerja yang besar,serta pendapatan dan perlindungan atas petani tembakau dan dampak lainnya. Menurut Kementerian Perindustrian Republik Indonesia (2020) industri rokok dan industri terkait menyerap sekitar 6.1 juta orang terutama wilayah penghasil tembakau, cengkeh dan pusatpusat produsen rokok. Namun disisi lain rokok juga memberikan efek negatif pada kesehatan penggunanya dikarenakan Menurut The Tobacco Atlas (2020) selain nikotin, didalam rokok juga memiliki terdapat berbagai jenis bahan kimia yaitu sekitar lebih dari 7.000 bahan kimia berbahaya termasuk arsenik, sianida, maupun zat berbahaya lainnya, dan lebih dari 50 zat yang berbahaya bagi tubuh manusia yang terkandung dalam rokok yang merupakan karsinogenik atau zat yang dapat memicu munculnya sel kanker.

Kebijakan mengenai kenaikan cukai rokok di Indonesia pada tahun 2020 sangat mempengaruhi harga saham dari perusahaan rokok. Harga saham yang turun akan menyebabkan actual return dan expected return menjadi turun yang menyebabkan adanya reaksi pada abnormal return baik positif maupun negatif. Harga saham yang turun juga akan mengakibatkan selisih antara jual dan beli juga akan menyempit sehingga bid-ask spread akan kecil yang akan menyebabkan meningkatnya transaksi jual dan beli dari saham perusahaan rokok sehingga trading volume activity akan meningkat.

Menurut Jogiyanto H. (2013), abnormal return adalah selidih dari return sebenarnya dengan return yang diharapkan. Return sebenarnya adalah imbal hasil yang didapatkan pada waktu ke-t yang merupakan selish antara harga saham pada saat ini dengan harga saham pada saat sebelumnya. Sedangkan return yang diharapkan adalah return yang merupakan hasil dari estimasi yang dilakukan investor atas investasi yang dilakukannya. 
Penelitian yang pernah dilakukan oleh peneliti sebelumnya menggunakan harga saham, abnormal return, trading volume activity sebagai variabel untuk melihat reaksi dari pasar modal terhadap suatu peristiwa yang dapat mempengaruhi pasar modal. Peneliti sebelumnya juga menggunakan berbagai event, seperti pengumuman paket kebijakan, pengumuman merger, pengumuman stock split, pengumuman tax amnesty dan berbagai kebijakan lainnya yang dapat mempengaruhi sikap investor. Menurut Ariyanti (2016) bahwa kebijakan pengendalian tembakau di indonesia menyebabkan sebelum dan sesudah pengumuman pada kebijakan menghasilkan perbedaan ARR (Average Abnormal Return) namun tidak signifikan. Sedangkan penelitian yang dilakukan Jennifer \& Komardi (2015) mengenai pembatasan iklan rokok yang menunjukkan bahwa tidak terdapat perbedaan yang signifikan antara kinerja keuangan perusahaan dan return saham sebelum dan sesudah penerapan peraturan periklanan pada perusahaan industri rokok.

Pergerakan yang terjadi pada volume perdagangan juga dapat menjadi indikasi bahwa terdapat informasi dalam sebuah peristiwa yang terjadi. Volume perdagangan sebgai inti dari sebuh kegiatan meramalkan ata pergerakan harga dari sebuah saham. Pada saat volume perdagangan mengalami kenaikan, biasanya terjadi penurunan harga saham yang diperjualbelikan maka diindikasikan pasar dalam kondisi bearish. Namun ketika volume perdagangan mengalami peningkatan pada saat harga mengalami kenaikan maka diindikasikan bahwa pasar dalam keadaan bullish. Sedangkan pada saat volume perdagangan menurun di waktu bersamaan harga saham menurun maka diindikasikan bahwa pasar dalam kondisi bullish. Sedangakan pada saat volume perdagangan mengalami penurunan pada saat harga saham mengalami penurunan maka diindikasikan bahwa pasar dalam kondisi bearish.

Pemerintah Republik Indonesia mengumumkan kenaikan harga cukai rokok dalam rangka melindungi anak-anak Indonesia dari paparan kecanduan rokok, tapi masih mempertimbangkan tenaga kerja yang masih bekerja di industri rokok sbelum terjadinya pengalihan industri, tenaga kerja diberikan pelatihan untuk dapat memasuki industri baru dan juga berkelanjutan di masa yang akan datang.

Penelitian sebelumnya yang berkaitan dengan pengaruh kebijakan terhadap trading volume activity, menurut Fahmi (2016) menyatakan bahwa kebijakan dari reverse stock split memiliki perbedaan sebelum maupun sesudah event yang signifikan terhadap volume perdagangan saham perusahaan.

Menurut Neal (1999) bid-ask spread adalah selisih dari harga jual terendah sebuah saham dengan harga beli tertinggi sebuah saham pada saat perdagangan bursa berakhir. Tingkat likuiditas sebuah saham yang diperdagangkan dapat berpengaruh terhadap biaya 
transaksi pada sebuah saham. Biaya yang dikenakan dalam sebuah transaksi dapat berpengaruh terhadap strategi dan keputusan jual atau beli seorang investor. Apabila biaya transaksi yang dikenakan renda maka volume perdagangan yang dihasilkan akan meningkat sedangkan apabila biaya transaksi yang dikenakan besar maka investor akan menerapkan strategi beli dan simpan. Sehingga dapat dikatakan bahwa bid-ask spread sangat berhubungan erat dengan pergerakan trading volume activity.

Penelitian yang dilakukan Janiantari (2014) mengenai perbedaan bid-ask spread dan abnormal return sebagai dampak dari pengumuman stock split. Hasilnya menunjukkan bahwa terdapat perbedaan signifikan dari bid-ask spread dan abnormal return baik sebelum dan sesudah pengumuman pemecahan saham. Penelitian yang dilakukan Prasiska (2018) mengenai analisis abnormal return dan bid-ask spread sebelum dan sesudah stock split pada perusahaan go public di BEI Tahun 2013 sampai dengan 2017 dengan hasil penelitian yang menyatakan terdapat perbedaan abnormal return baik sebelum dan sesudah pengumuman stock split dan tidak terdapat perbedaan bid-ask spread baik sebelum dan sesudah pengumuman stock split.

Berdasarkan pemaparan teori dan studi empiris, penelitian ini dapat di uji dengan 4 hipotesis, yaitu sebagai berikut.

$\mathrm{H}_{1}$ : Terdapat perbedaan average abnormal return sebelum dan sesudah pengumuman kebijakan kenaikan cukai rokok tahun 2020.

$\mathrm{H}_{2}$ : Terdapat perbedaan average volume activity sebelum dan sesudah pengumuman kebijakan kenaikan cukai rokok tahun 2020.

$\mathrm{H}_{3}$ : Terdapat perbedaan bid-ask spread sebelum dan sesudah pengumuman kebijakan kenaikan cukai rokok tahun 2020.

\section{METODE PENELITIAN}

Populasi dalam penelitian ini adalah perusahaan-perusahaan yang bergerak dalam bidang pembuatan rokok yang terdaftar di bursa efek Indonesia yang berjumlah empat perusahaan. Adapun perusahaan yang memenuhi syarat dan menjadi sampel dari penelitian ini terdiri dari empat perusahaan.

Periode pengamatan yang disebut juga jendela peristiwa (window event). Dimana suatu peristiwa diberitahukan kepada khalayak umum untuk pertama kali yang ditetapkan sebagai event date (t0), yang mana merupakan hari selama proses peristiwa itu terjadi. Pendekatan ari penelitian ini yaitu menggunakan metode event study dengan melakukan 
kegiatan observarsi terhadap average cumulative abnormal return, average cumulative abnormal volume dan average cumulative bid-ask spread pada saham perusahaan rokok.

Abnormal return merupakan return yang sebenarnya yang diberikan kepada investor berbeda dengan return yang diharapkan oleh investor. Pada penelitian ini untuk menghitung adanya abnormal return digunakan harga saham sebagai acuan. Hal ini disebabkan abnormal return yang muncul akan dipengaruhi oleh harga saham perusahaan terkait. Ada beberapa langkah dalam penghitungan abnormal return :

\section{Menghitung Actual Return}

Actual return merupakan penerimaan yang diterima oleh investor dari investasinya baik untuk maupun rugi yang dapat dihitung dengan rumus sebagai berikut :

$$
R_{i, t}=\frac{\left(P_{i, t}-P_{i, t-1}\right)}{P_{i, t}-1}
$$

\section{Menghitung Market Return}

Menurut Jogiyanto (2010) market return dapat dihitung dengan menggunakan perhitungan sebagai berikut :

$$
R_{m, t}=\frac{\left(\mathrm{IHSG}_{\mathrm{t}}-\mathrm{IHSG}_{\mathrm{t}-1}\right)}{\mathrm{IHSG}_{\mathrm{t}-1}}
$$

\section{Menghitung Expected Return}

Expected Return adalah return yang diharapkan oleh investor yang akan terjadi dimasa yang akan datang. Dalam penelitian ini digunakan model Capital Asset Pricing Model (CAPM) dalam mengukur besarnya return ekspektasi. Model ini beranggapan bahwa proyeksi pada suatu periode yang individu yang memiliki anggapan yang sama mengenai kondisi pasar dan menghitung mean-variance dari sebuah portofolio yang optimal.

Menurut Jogiyanto (2010) menghitung return dari pasar dapat dilakukan dengan rumus sebagai berikut :

$$
\mathrm{R}_{\mathrm{m}, \mathrm{t}}=\frac{\left(\mathrm{IHSG}_{\mathrm{t}}-\mathrm{IHSG}_{\mathrm{t}-1}\right)}{\mathrm{IHSG}_{\mathrm{t}-1}}
$$

Risiko sistematis atau beta (ß) merupakan sebuah resiko yang muncul dari adanya perbedaan antara return dari suatu saham dengan return di pasar, dengan kata lain beta merupakan pembagian dari kovarian sebuah saham dengan varian pasar.

$$
\beta \mathrm{i}=\frac{\sigma_{\mathrm{im}}}{\sigma_{\mathrm{m}}^{2}}
$$


Menurut Jogiyanto (2010) Expected return dapat dihitung dengan menggunakan rumus sebagai berikut :

$E\left(R_{i, t}\right)=R f+\beta_{i}\left\{E\left(R_{m, t}\right)-R f\right\}$

\section{Menghitung Abnormal Return}

Menurut Jogiyanto (2010) abnormal return dapat dihitung dengan menggunakan rumus sebagai berikut :

$$
\mathrm{AR}_{\text {it }}=\mathrm{R}_{\mathrm{it}}-\mathrm{E}\left(\mathrm{R}_{\mathrm{it}}\right)
$$

Volume perdagangan suatu saham dapat dihitung dengan menggunakan perhitungan sebagai berikut :

$$
\mathrm{TVA}_{\mathrm{it}}=\frac{\Sigma \text { saham i yang ditransaksikan pada waktu } \mathrm{t}}{\Sigma \text { saham i yang terdaftar }}
$$

Menghitung rata-rata Trading Volume Activity

$$
\begin{aligned}
& \text { ATVA }_{\text {it }} \text { before }=\frac{\Sigma T V A_{i t} \text { before }}{n} \\
& \text { ATVA }_{\text {it }} \text { after }=\frac{\Sigma T V A_{i t} \text { after }}{n}
\end{aligned}
$$

Bid-ask spread diukur dengan menggunakan rumus sebagai berikut:

\begin{tabular}{|c|c|c|c|c|}
\hline No & Variabel & Definisi Variabel & Pengukuran & Skala \\
\hline \multirow[t]{2}{*}{1} & \multirow[t]{2}{*}{ Abnormal Return } & \multirow{2}{*}{$\begin{array}{l}\text { Perbandingan antara } \\
\text { abnormal return dengan } \\
\text { jumlah sampel }\end{array}$} & EARit & \multirow[t]{2}{*}{ Rasio } \\
\hline & & & $\mathrm{n}$ & \\
\hline \multirow[t]{2}{*}{2} & \multirow{2}{*}{$\begin{array}{l}\text { Trading Volume } \\
\text { Activity }\end{array}$} & \multirow{2}{*}{$\begin{array}{l}\text { Perbandingan antara volume } \\
\text { saham dengan jumlah saham } \\
\text { beredar }\end{array}$} & \multirow{2}{*}{$\frac{\Sigma \text { saham i yang ditransaksikan pada waktu } t}{\Sigma \text { saham i yang terdaftar }}$} & \multirow[t]{2}{*}{ Rasio } \\
\hline & & & & \\
\hline 3 & Bid-Ask Spread & $\begin{array}{l}\text { Perbandingan antara ask } \\
\text { price dengan bid price }\end{array}$ & $\frac{\text { ask price }_{\text {it }}-\text { bid price }_{\text {it }}}{\left(\text { ask price }_{\text {it }}+\text { bid price }\right.}$ & Rasio \\
\hline
\end{tabular}

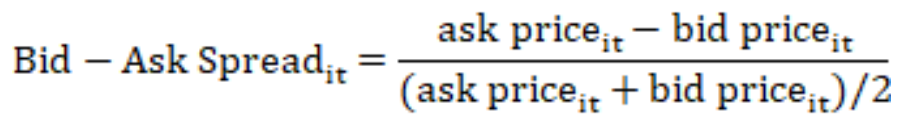

\section{Tabel 1.}

Definisi Variabel Operasional dan Pengukuran 


\section{HASIL PENELITIAN DAN PEMBAHASAN}

Teknik pengolahan dan analisis data dalam penelitian ini dilakukan dengan uji Paired Sample T-test, dengan syarat data berdistribusi normal dengan menggunakan uji Kolmogorov-Smirnov Test. Tabel 2 dapat dilihat bahwa Average Abnormal Return (AAR) sebelum dan sesudah peristiwa pengumuman kenaikan cukai rokok. AAR sebelum event terendah terjadi pada t-10 yaitu -0.029 dan pada t-8 mengalami kenaikan disebabkan oleh reaksi positif pasar yaitu 0.015 , pada t-7 mengalami penurunan kembali disebabkan reaksi negatif pada saham HMSP dan WIIM yaitu -0.006, pada t-6 mengalami kenaikan tipis disebabkan saham GGRM dan HMSP yang memiliki abnormal return negatif yaitu 0.001 namun dapat diimbangi dengan kinerja saham yang bagus dari RMBA.

Pada t-5 mengalami kenaikan kembali yaitu 0.008 disebabkan kinerja saham WIIM dan HMSP yang baik namun saham GGRM masih belum memberikan kinerja positif. AAR tertinggi pada t-4 yaitu 0.019 disebabkan semua saham perusahaan rokok memberikan Abnormal Return kemudian pada t-3 tiga perusahaan memiliki abnormal return kecuali HMSP yaitu -0.022 walaupun tidak memberikan abnormal return, pada t-2 mengalami kenaikan yang disebabkan kinerja saham yang sedang bagus dan pada t-1 saham HMSP, RMBA dan WIIM yang memberikan kinerja saham yang positif yaitu 0.014. AAR terendah setelah terjadinya kenaikan cukai terjadi pada $\mathrm{t}+1$ yaitu -0.028 dikarenakan terjadinya reaksi pasar yang negatif dan masif pada saham perusahaan yang menyebabkan kinerja saham GGRM dan HMSP mengalami penurunan yang cukup tajam yang menyebabkan AAR negatif.

Kenaikan AAR pada t+2 yaitu 0.009 ditopang oleh kinerja yang lebih baik dari GGRM, HMSP dan WIIM sedangkan kenaikan pada t+3 yaitu 0.012 ditopang oleh kinerja saham yang baik pada saham RMBA dan WIIM. AAR yang positif berlangsung $t+4$ sampai t+8 yang disebabkan kinerja saham GGRM yang bagus pada periode tersebut, AAR yang tertinggi terjadi pada $\mathrm{t}+7$ yaitu 0.038 yang disebabkan kinerja saham yang baik dari GGRM dan HMSP sedangkan pada t+9 AAR bernilai negatif yaitu -0.010 disebabkan oleh kinerja saham GGRM dan HMSP yang memburuk kemudian pada t+10 AAR kembali naik yaitu 0.017 disebabkan kinerja saham GGRM dan HMSP yang bagus.

Cummulative average abnormal return sebelum pengumuman kebijakan kenaikan cukai bernilai negatif yang disebabkan Abnormal return yang dihasilkan perusahaan cenderung negatif terutama saham GGRM dan HMSP yang mempunyai pangsa pasar besar pada industri rokok sedangkan Cummulative average abnormal return setelah pengumuman kebijakan kenaikan cukai bernilai positif walaupun AAR pada 1 hari setelah pengumuman 
mengalami reaksi negatif namun Abnormal Return yang dihasilkan Perusahaan rokok cenderung positif setelah pengumuman kebijakan kenaikan cukai dikarenakan masih tingginya pengguna rokok di Indonesia.

Tabel 2.

Average Abnormal Return sebelum dan sesudah Pengumuman Kenaikan Cukai Rokok 2020

\begin{tabular}{cccccc}
\hline Periode & AAR & CAAR & Periode & AAR & CAAR \\
\hline $\mathrm{t}-10$ & -0.029 & -0.029 & $\mathrm{t}+1$ & -0.028 & -0.028 \\
$\mathrm{t}-9$ & -0.028 & -0.058 & $\mathrm{t}+2$ & 0.009 & -0.019 \\
$\mathrm{t}-8$ & 0.015 & -0.014 & $\mathrm{t}+3$ & 0.012 & 0.021 \\
$\mathrm{t}-7$ & -0.006 & 0.009 & $\mathrm{t}+4$ & 0.026 & 0.037 \\
$\mathrm{t}-6$ & 0.001 & -0.005 & $\mathrm{t}+5$ & 0.006 & 0.032 \\
$\mathrm{t}-5$ & 0.008 & 0.009 & $\mathrm{t}+6$ & 0.008 & 0.014 \\
$\mathrm{t}-4$ & 0.019 & 0.026 & $\mathrm{t}+7$ & 0.038 & 0.046 \\
$\mathrm{t}-3$ & -0.022 & -0.003 & $\mathrm{t}+8$ & 0.013 & 0.051 \\
$\mathrm{t}-2$ & 0.014 & -0.008 & $\mathrm{t}+9$ & -0.010 & 0.003 \\
$\mathrm{t}-1$ & 0.008 & 0.022 & $\mathrm{t}+10$ & 0.017 & 0.007
\end{tabular}

Sumber: Data Olahan, 2020

Berdasarkan Tabel 3 dapat dilihat bahwa trading volume activity yang terjadi t-10 dan t-9 terjadi peningkatan transaksi yaitu 0.001 peningkatan terjadi pada saham GGRM, HMSP dan WIIM yang disebabkan penurunan harga saham GGRM, HMSP dan WIIM. Sedangkan TVA terbesar terjadi pada t-1yaitu 0.001 peningkatan transaksi terjadi terutama pada saham GGRM dan WIIM. Sedangkan pada $t+1$ terjadi TVA yang cukup tinggi yaitu 0.002 peningkatan transaksi terjadi terutama pada saham GGRM, HMSP dan WIIM disebabkan reaksi pasar pada pengumuman kenaikan cukai di hari sebelumnya kemudian pada hari selanjutnya TVA cenderung stabil yang disebabkan kepercayaan investor bahwa perusahaan rokok masih dapat bertahan apabila terjadi kenaikan cukai.

Kenaikan cukai tidak mempengaruhi saham RMBA dikarenakan volume yang diperdagangkan tidak terlalu besar sehingga terlihat stabil. Average trading volume activity sebelum pengumuman kebijakan kenaikan cukai cenderung stabil namun 1 hari setelah pengumuman kenaikan cukai terjadi kenaikan transaksi jual dan beli di bursa ini menandakan bahwa kenaikan cukai dapat memberikan sentimen pada bursa terutama investor yang berinvestasi pada industri rokok. Secara keseluruhan kenaikan cukai rokok tidak terlalu mempengaruh transaksi jual-beli saham rokok di pasar modal. 


\section{Tabel 3.}

Average Trading Volume Activity sebelum dan sesudah Pengumuman Kenaikan Cukai Rokok 2020

\begin{tabular}{cccc}
\hline Periode & Sebelum & Periode & Sesudah \\
\hline t-10 & 0.001 & $\mathrm{t}+1$ & 0.002 \\
$\mathrm{t}-9$ & 0.001 & $\mathrm{t}+2$ & 0.001 \\
$\mathrm{t}-8$ & 0.000 & $\mathrm{t}+3$ & 0.001 \\
$\mathrm{t}-7$ & 0.000 & $\mathrm{t}+4$ & 0.000 \\
$\mathrm{t}-6$ & 0.000 & $\mathrm{t}+5$ & 0.000 \\
$\mathrm{t}-5$ & 0.000 & $\mathrm{t}+6$ & 0.000 \\
$\mathrm{t}-4$ & 0.000 & $\mathrm{t}+7$ & 0.000 \\
$\mathrm{t}-3$ & 0.000 & $\mathrm{t}+8$ & 0.000 \\
$\mathrm{t}-2$ & 0.000 & $\mathrm{t}+9$ & 0.001 \\
$\mathrm{t}-1$ & 0.001 & $\mathrm{t}+10$ & 0.000 \\
\hline
\end{tabular}

Sumber: Data Olahan, 2020

Berdasarkan Tabel 3 dapat dilihat bahwa Bid-Ask Spread yang terjadi pada t-10 selisih antara harga jual terendah dengan harga beli tertinggi yaitu 0.069 pada saham RMBA terlalu besar sehingga akan berdampak pada TVA pada saham RMBA. Hal ini dapat dilihat kurangnya reaksi pasar pada volume transaksi pada saham RMBA, selisih yang besar juga terjadi pada t-6 yaitu 0.035 , t-4 yaitu 0.041 , t-2 yaitu 0.036 dan t-1 yaitu 0.017 yang mengakibatkan turunnya volume transaksi pada saham RMBA. Pada saham WIIM terjadi kesamaan pada B-AS pada periode $\mathrm{t}-10, \mathrm{t}-8, \mathrm{t}-7, \mathrm{t}-6, \mathrm{t}-5, \mathrm{t}-3$ dan $\mathrm{t}-2$ yaitu 0.010 yang menyebabkan investor tertarik pada saham yang dibeli karena memiliki return yang relatif stabil. Sedangkan pada $t+1$ dapat dilihat bahwa B-AS cenderung kecil yaitu 0.004 dikarenakan transaksi jual lebih banyak dari pada transaksi beli yang menyebabkan banyaknya penawaran di pasar sehingga harga jual saham turun, sedangkan pada $t+2$ sampai t+10 saham yang memiliki selisih yang besar masih ditawarkan oleh saham RMBA hal ini menyebabkan sulitnya saham RMBA dapat memperbesar transaksi di pasar modal.

Average bid ask spread cenderung fluktuatif, AB-AS tertinggi terjadi pada t-10 yaitu 0.021 yang disebabkan oleh BA-S dari saham RMBA yang cukup signifikan sedangkan ABAS terendah terjadi pada t-9 yaitu 0.004 dikarenakan menurunnya BA-S dari RMBA yang dapat menaikkan volume transaksi dari saham RMBA. Sedangkan setelah pengumuman kenaikan cukai pada 1 hari setelah pengumuman terjadi sentimen yang kurang baik karena harga jual dan harga beli memiliki selisih yang mengecil yang disebabkan transaksi jual yang cukup besar yaitu 0.004 sehingga penawaran yang lebih besar dari pada permintaan menyebabkan turunnya harga saham perusahaan rokok namun hari selanjutnya terjadi 
peningkatan kembali yang menandakan investor masih tertarik pada saham perusahaan rokok. Hal ini dapat dilihat pada nilai volume perdagangan bergerak fluktuatif seiring dengan pergerakan nilai transaksi saham yang cenderung bergerak fluktuatif juga.

Tabel 4.

Bid-Ask Spread sebelum dan sesudah Pengumuman Kenaikan Cukai Rokok 2020

\begin{tabular}{cccc}
\hline Periode & Sebelum bid ask & Periode & Sesudah bid ask \\
\hline $\mathrm{t}-10$ & 0.021 & $\mathrm{t}+1$ & 0.004 \\
$\mathrm{t}-9$ & 0.004 & $\mathrm{t}+2$ & 0.010 \\
$\mathrm{t}-8$ & 0.005 & $\mathrm{t}+3$ & 0.009 \\
$\mathrm{t}-7$ & 0.005 & $\mathrm{t}+4$ & 0.014 \\
$\mathrm{t}-6$ & 0.013 & $\mathrm{t}+5$ & 0.019 \\
$\mathrm{t}-5$ & 0.007 & $\mathrm{t}+6$ & 0.014 \\
$\mathrm{t}-4$ & 0.014 & $\mathrm{t}+7$ & 0.011 \\
$\mathrm{t}-3$ & 0.006 & $\mathrm{t}+8$ & 0.011 \\
$\mathrm{t}-2$ & 0.013 & $\mathrm{t}+9$ & 0.008 \\
$\mathrm{t}-1$ & 0.008 & $\mathrm{t}+10$ & 0.013
\end{tabular}

Sumber: Data Olahan, 2020

Uji normalitas digunakan untuk mengetahui apakah data yang diperoleh berdistribusi normal atau tidak. Hasil uji normalitas dapat dilihat dengan menggunakan uji One Sample Kolmogorov Smirnov.

Tabel 5

Hasil Uji Kolmogorov-Smirnov

\begin{tabular}{llll}
\hline \multicolumn{1}{c}{ Variabel } & KS & Sig & Keterangan \\
\hline Abnormal Return sebelum & 0.506 & 0.960 & Normal \\
Abnormal Return sesudah & 0.389 & 0.998 & Normal \\
Trading volume activity sebelum & 0.484 & 0.973 & Normal \\
Trading volume activity sesudah & 0.831 & 0.494 & Normal \\
Bid-ask spread sebelum & 0.702 & 0.707 & Normal \\
Bid-ask spread sesudah & 0.501 & 0.963 & Normal \\
Bid-ask spread sesudah & 0.501 & 0.963 & \\
\hline
\end{tabular}

Sumber: Data Olahan, 2020

Berdasarkan hasil uji normalitas diperoleh analisis sebagai berikut:

- Nilai Asymp. Sig dari Abnormal Return sebelum pengumuman kenaikan cukai tahun 2020 adalah $0.782>0.05$, maka data berdistribusi normal.

- Nilai Asymp. Sig dari Abnormal Return sesudah pengumuman kenaikan cukai tahun 2020 adalah $0.654>0.05$, maka data berdistribusi normal. 
- Nilai Asymp. Sig dari Trading Volume Activity sebelum pengumuman kenaikan cukai tahun 2020 adalah $0.973>0.05$, maka data berdistribusi normal

- Nilai Asymp. Sig dari Trading Volume Activity sesudah pengumuman kenaikan cukai tahun 2020 adalah $0.494>0.05$, maka data berdistribusi normal

- Nilai Asymp. Sig dari Bid-ask Spread sebelum pengumuman kenaikan cukai tahun 2020 adalah $0.707>0.05$, maka data berdistribusi normal

- Nilai Asymp. Sig dari Bid-ask Spread sesudah pengumuman kenaikan cukai tahun 2020 adalah $0.963>0.05$, maka data berdistribusi normal

Uji t digunakan untuk mengetahui pengaruh dari masing-masing variabel yaitu abnormal return, trading volume activity dan bid-ask spread dan melihat apakah pengaruhnya sginifan atau tidak pada tingkat signifikansi $\alpha=5 \%$

\section{Tabel 6}

Hasil Uji T

\begin{tabular}{ccccc}
\hline Variabel & T Hitung & T tabel & Sig & Hasil \\
\hline CAAR & -3.239 & 2.262 & 0.010 & Perbedaan Negatif dan Signifikan \\
ATVA & -0.850 & 2.262 & 0.417 & Tidak Terdapat Perbedaan \\
AB-A S & -0.721 & 2.262 & 0.489 & Tidak Terdapat Perbedaan
\end{tabular}

Sumber: Data Olahan, 2020

\section{Perbedaan average Abnormal return}

Berdasarkan tabel 6 menjelaskan bahwa nilai t hitung dari abnormal return sebelum dan sesudah pengumuman sebesar -3.239 lebih besar dari t tabel sebesar 2.262 dan nilai signifikansi dari cummulative average abnormal return sebesar 0.010 lebih kecil dari tingkat signifikansi 0.05. Maka H0 ditolak dan Ha diterima, sehingga disimpulkan bahwa terdapat perbedaan negatif dan signifikan terhadap abnormal return sebelum dan sesudah kebijakan kenaikan cukai rokok tahun 2020.

Berdasarkan hasil penelitian diketahui bahwa abnormal return memiliki perbedaan negatif dan signifikan sebelum maupun sesudah pengumuman kebijakan kenaikan cukai rokok tahun 2020. Adanya perbedaan yang negatif pada abnormal return sejalan dengan teori Efficient Market Hyphothesis (EMH) yang menyatakan pada pasar efisien setengah kuat jika harga-harga sekuritas saham secara penuh mencerminkan semua informasi yang dipublikasikan (all publicly available information) termasuk informasi yang berada di laporan-laporan keuangan sehingga harga saham perusahaan rokok sebelum maupun sesudah event akan dipengaruhi informasi yang dipublikasi, walaupun pemerintah menjaga perusahaan rokok agar tetap bertahan, tidak dipungkiri penyerapan tenaga kerja untuk industri rokok cukup besar namun disisi lain pemerintah harus mengatur kenaikan cukai untuk 
melindungi kesehatan masyarakat dan generasi muda agar terhindar dari bahaya rokok sehingga menyebabkan terjadinya perbedaan CAAR yang negatif dan signifikan yang disebabkan adanya kenaikan cukai.

Berdasarkan analisis deskriptif bahwa selama periode pengamatan rata-rata abnormal return mengalami fluktuasi. Pada satu hari setelah pengumuman kenaikan cukai rokok tahun 2020 terjadi penurunan return yang cukup drastis. Namun terjadi peningkatan setelahnya yang disebabkan karena investor masih memiliki kepercayaan pada perusahaan rokok di masa yang datang, melihat masih baiknya analisis fundamental pada perusahaan rokok.

Berdasarkan hasil uji hipotesis abnormal return sejalan dengan hipotesis yang ada hal ini terjadi disebabkan reaksi negatif pada abnormal return pada satu hari setelah event kemudian kembali meningkat setelahnya ini menandakan bahwa kebijakan yang dikeluarkan pemerintah mempengaruhi secara signifikan terhadap reaksi negatif investor di pasar modal terhadap perusahaan rokok yang menyababkan harga saham perusahaan rokok menurun.

Temuan penelitian ini mendukung penelitian Ariyanti (2016) yang menyatakan terdapat perbedaan signifikan pada abnormal return sebelum dan sesudah event walaupun reaksi negatif hanya terjadi pada 1 hari sesudah pengumuman kebijakan cukai roko namun penurunan cukup mempengaruhi abnormal return terutama setelah terjadinya event karena menurut laporan The Tobacco Atlas (2020) pengguna rokok di Indonesia diprediksi bertambah 24 juta orang antara 2015-2025 sedangkan jumlah konsumsi rokok di Indonesia juga diketahui cukup tinggi yaitu mencapai 1.675 batang per kapita dalam satu tahun sehingga investor masih berpikir bahwa saham perusahaan rokok merupakan saham yang cukup kuat untuk dipertahankan walaupun terjadi kenaikan cukai rokok namun hasil dari penelitian ini bertolak belakang dengan penelitian Gumanti (2018) yang menyatakan tidak adanya perbedaan abnormal return yang signifikan periode sebelum dan sesudah peristiwa disebabkan peristiwa yang diteliti kurang merepresentasikan industri penginapan di Malaysia akan dapat dipengaruhi dengan adanya kejatuhan pesawat AirAsia apalagi maskapai yang terbang ke Malaysia bukan hanya maskapai AirAsia saja.

\section{Perbedaan average Trading Volume Activity}

Berdasarkan tabel 6 menjelaskan bahwa nilai t hitung dari Trading Volume Activity sebelum dan sesudah pengumuman sebesar -0.850 lebih kecil dari t tabel sebesar 2.262 dan nilai signifikansi dari average Trading Volume Activity sebesar 0.417 lebih besar dari tingkat signifikansi 0.05. Maka H0 diterima dan Ha ditolak, sehingga disimpulkan bahwa tidak 
terdapat perbedaan average Trading Volume Activity sebelum dan sesudah kebijakan kenaikan cukai rokok tahun 2020.

Berdasarkan hasil penelitian diketahui bahwa Trading Volume Activity tidak memiliki perbedaan sebelum maupun sesudah pengumuman kebijakan kenaikan cukai rokok tahun 2020. Tidak adanya perbedaan Trading Volume Activity ini sejalan dengan teori Efficient Market Hyphothesis (EMH) yang menyatakan pada pasar efisien setengah kuat jika harga-harga sekuritas saham secara penuh mencerminkan semua informasi yang dipublikasikan (all publicly available information) termasuk informasi yang berada di laporan-laporan keuangan, abnormal return yang menurun drastis dapat meningkatkan transaksi pada pasar modal yang dikarenakan adanya reaksi cepat investor namun kemudian transaksi kembali normal apabila abnormal return kembali bernilai positif.

Berdasarkan analisis deskriptif bahwa selama periode pengamatan rata-rata trading volume activity mengalami fluktuasi. Pada satu hari setelah pengumuman kenaikan cukai rokok tahun 2020 terjadi kenaikan pada transaksi pada saham perusahaan rokok. Hal ini disebabkan karena reaksi investor terhadap kebijakan kenaikan cukai yang diumumkan oleh pemerintah.

Berdasarkan hasil uji hipotesis trading volume activity tidak sejalan dengan hipotesis yang ada walaupun terjadi peningkatan transaksi pada satu hari setelah event tidak menjamin adanya reaksi pasar yang cukup besar yang dapat mempengaruhi transaksi di hari selanjutnya apalagi perusahaan rokok memiliki modal fundamental yang kuat untuk mempertahankan pasar agar tidak bereaksi berlebihan ini ditunjukkan pada hari-hari berikutnya yang ditandai menurunnya transaksi yang hampir sama dengan sebelum terjadinya event.

Temuan penelitian ini mendukung penelitian Gumanti (2018) yang menyatakan tidak terdapat perbedaan Trading Volume Activity sebelum dan sesudah event, ini disebabkan walaupun ada peningkatan transaksi pada 1 hari setelah event tidak menjamin pasar akan bereaksi dengan melakukan kegiatan jual beli saham secara besar-besaran yang berakibat terjadi perbedaan sebelum dan setelah event namun hasil dari penelitian ini bertolak belakang dengan penelitian Fahmi (2016) yang menyatakan adanya perbedaan abnormal return yang signifikan Trading volume Activity periode sebelum dan sesudah peristiwa, ini disebabkan keputusan perusahaan yang melakukan reverse stock split yang akan membuat transaksi meningkat secara signifikan karena berkurang nilai saham sehingga jumlah yang dibeli dengan uang sama sebelum stock split akan bertambah jumlah yang didapat setelah terjadi stock split. 


\section{Perbedaan average Bid-Ask Spread}

Berdasarkan tabel 6 menjelaskan bahwa nilai t hitung dari average Bid-Ask Spread sebelum dan sesudah pengumuman sebesar -0.721 lebih kecil dari t tabel sebesar 2.262 dan nilai signifikansi dari average Bid-Ask Spread sebesar 0.489 lebih besar dari tingkat signifikansi 0.05. Maka H0 diterima dan Ha ditolak, sehingga disimpulkan bahwa tidak terdapat perbedaan average Bid-Ask Spread sebelum dan sesudah kebijakan kenaikan cukai rokok tahun 2020 .

Berdasarkan hasil penelitian diketahui bahwa Bid-Ask Spread tidak memiliki perbedaan sebelum maupun sesudah pengumuman kebijakan kenaikan cukai rokok tahun 2020. Tidak adanya perbedaan Bid-Ask Spread ini sejalan dengan teori Efficient Market Hyphothesis (EMH) yang menyatakan pada pasar efisien setengah kuat jika harga-harga sekuritas saham secara penuh mencerminkan semua informasi yang dipublikasikan (all publicly available information) termasuk informasi yang berada di laporan-laporan keuangan yang menandakan biaya transaksi sangat berkaitan dengan harga saham sehingga jika harga saham naik maka biaya transaksi akan naik apabila harga saham turun maka biaya transaksi akan turun juga. Penurunan biaya transaksi yang disebabkan penurunan harga jual saham dan harga beli saham yang cukup besar sehingga biaya transaksi menjadi lebih murah namun karena harga saham perusahaan rokok cukup stabil setelah event sehingga tidak terjadi penurunan biaya transaksi pada saham perusahaan rokok yang berimplikasi pada stagnannya volume transaksi saham perusahaan rokok.

Berdasarkan analisis deskriptif bahwa selama periode pengamatan rata-rata bid-ask spread mengalami fluktuasi. Pada satu hari setelah pengumuman kenaikan cukai rokok tahun 2020 terjadi penurunan pada biaya transaksi saham pada perusahaan rokok. Hal ini menyebabkan peningkatan transaksi pada saham perusahaan rokok.

Berdasarkan uji hipotesis bid-ask spread tidak sejalan dengan hipotesis yang ada, ini disebabkan walaupun terjadi penurunan biaya transaksi yang merupakan selisih antara harga jual terendah dan harga beli tertinggi mengalami penurunan yang diakibatkan oleh kebijakan kenaikan cukai sehingga transaksi meningkat namun biaya transaksi yang rendah tidak bertahan lama disebabkan terjadinya peningkatan harga saham rokok sehingga biaya transaksi kembali ke harga sebelum terjadinya event.

\section{SIMPULAN}

Cummulative average abnormal return memiliki perbedaan negatif dan signifikan baik sebelum maupun sesudah pengumuman kebijakan kenaikan cukai rokok tahun 2020, 
investor bereaksi cepat pada setelah pengumuman kenaikan cukai yang ditandai dengan nilai negatif dari rata-rata Abnormal Return. Bahwa kebijakan yang dikeluarkan pemerintah untuk mengurangi konsumsi rokok dengan menaikan cukai rokok mempengaruhi secara signifikan terhadap reaksi pasar modal terhadap perusahaan rokok dikarenakan apabila cukai naik maka perusahaan akan menaikkan harga jual, harga jual yang naik akan mengurangi daya beli masyarakat sehingga penjualan rokok akan berkurang. Hal ini menunjukkan reaksi pasar modal yang terjadi mempengaruhi abnormal return.

Average trading volume activity tidak memiliki perbedaan baik sebelum maupun sesudah pengumuman kebijakan kenaikan cukai rokok tahun 2020, investor bereaksi normal sebelum adanya pengumuman kenaikan cukai namun setelah adanya pengumuman kenaikan cukai rokok terjadi peningkatan volume perdagangan saham rokok. Walaupun terjadi peningkatan transaksi pada satu hari setelah event tidak menjamin adanya reaksi pasar yang cukup besar yang dapat mempengaruhi transaksi di hari selanjutnya apalagi perusahaan rokok memiliki modal fundamental yang kuat. Hal ini menunjukkan reaksi pasar modal yang terjadi tidak mempengaruhi trading volume activity.

Average bid-ask spread tidak memiliki perbedaan baik sebelum maupun sesudah pengumuman kebijakan kenaikan cukai rokok tahun 2020, pergerakan bid-ask spread cenederung fluktuatif pada sebelum pengumuman kenaikan cukai seiring pergerakan harga saham sedangkan setelah pengumuman kenaikan cukai terjadi penurunan bid-ask spread yang disebabkan adanya penurunan harga saham perusahaan rokok. Walaupun terjadi penurunan biaya transaksi yang merupakan selisih antara harga jual terendah dan harga beli tertinggi mengalami penurunan yang diakibatkan oleh kebijakan kenaikan cukai sehingga transaksi meningkat namun biaya transaksi yang rendah tidak bertahan lama di sebabkan terjadinya peningkatan harga saham rokok. Hal ini menunjukkan reaksi pasar modal yang terjadi tidak mempengaruhi bid-ask spread.

Investor diharapkan untuk mencari dan mengelaborasi informasi baik yang terdapat di pasar modal ataupun dari sumber lain yang dapat dipercaya sebanyak-banyaknya sebelum mengambil keputusan dalam membeli saham dari perusahaan rokok. Investor juga harus mempertimbangkan faktor-faktor yang mempengaruhi kondisi pasar dan faktor lain yang dapat mempengaruhi pasar modal.

Investor diharapkan dapat mempelajari lebih banyak tentang kebijakan, regulasi, makro ekonomi dan aksi korporasi yang dapat mempengaruhi harga saham sehingga investor dapat melakukan tindakan yang tepat dalam berinvestasi.

Peneliti selanjutnya diharapkan dapat menambah variabel dalam penelitian yang 
dapat mempengaruhi kebijakan kenaikan cukai agar dapat menambahkan lebih banyak informasi tambahan yang lebih baik. Peneliti selanjutnya juga diharapkan dapat merubah metode pengukuran expected return dengan menggunakan market adjusted model, mean model, market model dan model estimasi lainnya agar dapat mendapatkan informasi yang lebih baik serta mengetahui metode apa yang paling sesuai dalam menilai reaksi pasar modal.

\section{REFERENSI}

Ammann et al. (2015). Efek Pengumuman Dari Convertible Securities (Obligasi Coco) yang diterbitkan Oleh Bank Global Antara Januari 2009 dan Juni 2014.

Ariyanti, R. (2016). Reaksi Pasar Modal Atas Kebijakan Pengendalian Tembakau di Indonesia: Event Study Pada Saham Industri Rokok di Bursa Efek Indonesia.

Bei, V. N. (2015). Dampak Penerapan Kebijakan Loan To Value Terhadap Reaksi Pasar Modal di Bursa Efek Indonesia (BEI): Sebuah Pendekatan Event Study.

Brigham \& Houston. (2011). Dasar-Dasar Manajemen Keuangan (II). Jakarta: Salemba Empat.

Fahmi, Ahmad et al. (2016). Pengaruh Kebijakan Reverse Stock Split Terhadap Volume Perdagangan Saham Perusahaan Go Public yang Terdaftar Dalam Bursa Efek Indonesia Tahun 2003-2013, Vol 2 No. 3, 246-259.

Fama, E. F. (1970). stock market prices, Financial Analysts Journal. Vol. 51 No. 1, 55-59.

Gumanti, T. A., et al. (2018). Event Study on the Crash of Airasia Plane: A Study on Travel and Leisure Companies Listed at Malaysian Stock Market, Vol. 20 No. 1, 20-26. doi:10.9744/jak.20.1.20-26

Janiantari, I. G. (2014). Analisis Perbedaan Bid-ask Spread dan Abnormal Return Saham Sebagai Dampak dari Pengumuman Stock Split. E-Jurnal Akuntansi Universitas Udayana, 267-282.

Jennifer., \& Komardi, D. (2015). Analisis Perbedaan Kinerja Keuangan Perusahaan dan Return Saham Sebelum dan sesudah Penerapan Peraturan Periklanan Rokok Pada Perusahaan Industri Rokok yang Go Public di BEI Periode 2012-2014.

Jogiyanto.H (2010). Analisis dan Desain Sistem Informasi. Yogyakarta: Andi Offset.

Jogiyanto, H. (2003). Teori Portofolio Dan Analisis Investasi. Yogyakarta: BPFE UGM.

Jogiyanto, H. (2013). Teori Investasi dan Portofolio. Yogyakarta: BPFE UGM.

Kasmir. (2012). Bank dan Lembaga Keuangan Lainnya. Jakarta: Raja Grafindo Pustaka.

Kementerian Perindustrian Republik Indonesia. (2020). Gambaran Rokok.

Laili, D. I. (2017). Abnormal Retum dan Trading Volume Activity Sebelum dan Sesudah Pengumuman Kenaikan Cukai Rokok Periode 2016 (Study Kasus pada Industri Rokok 
yang terdaftar di Bursa Efek Indonesia).

Puteri, L. P. (2017). Analysis of Differences on Abnormal Return And Trading Volume Activity (TVA) Because of Increasing Cigarette Price (Study at Stocks Listed in LQ45 index on August 2016-January 2017), Vol. 50 No. 4.

Rofiki, David et al. (2018). Reaksi Pasar Modal Indonesia Akibat Peristiwa Pemilihan Gubernur DKI Jakarta Putaran II 2017 (Event Study Pada Saham Perusahaan yang Terdaftar di Indeks LQ45 Periode Februari-Juli 2017).

Scoot, W. R. (2012). Financial Accounting Theory International Fifth Edition. New Jersey: Prentice Hall Inc.

The Tobacco Atlas. (2020). Country Fact Sheet : Indonesia. Dipetik January 17, 2020, dari The Tobacco Atlas: https://tobaccoatlas.org/country/indonesia/

Vahini, Y. P., \& Putra, N. W. (2015). Event Study : Analisis Reaksi Investor pada Publikasi Laporan Keuangan Tahunan, 13. No. 2, 387-404. 